\title{
SOME MEDICINAL PROPERTIES OF GLYCYRRHIZA GLABRA (LICORICE)
}

\author{
GLYCYRRHIZA GLABRA'NIN BAZI TIBBİ ÖZELLIKLLERI (MEYAN KÖKÜ)
}

\section{Falah Saleh MOHAMMED ${ }^{1}$ (D), Nuh KORKMAZ ${ }^{2 *}$ (D), Mehmet DOĞAN ${ }^{3}$ (D),}

\author{
Ali Erdem ŞABİK ${ }^{4}$ (D), Mustafa SEVİNDİK ${ }^{3}$
}

${ }^{1}$ Duhok University, Science Faculty, Department of Biology, 42001, Duhok, Iraq

${ }^{2}$ Osmaniye Korkut Ata University, Science and Literature Faculty, Department of Biology, 80000,

Osmaniye, Turkey

${ }^{3}$ Osmaniye Korkut Ata University, Bahçe Vocational School, Department of Food Processing, 80500, Osmaniye, Turkey

${ }^{4}$ Osmaniye Korkut Ata University, Bahce Vocational School, Department of Chemistry and Chemical Processing Technologies, 80500, Osmaniye, Turkey

\begin{abstract}
Objective: Alternative medicine has an important place in the fight against many diseases in human history. The biological activity of Glycyrrhiza glabra L. was investigated in this study.

Material and Method: The root parts of the plant were extracted with ethanol. Antioxidant and oxidant potentials were determined using Rel Assay kits. Antimicrobial activity was tested against standard bacteria and fungus strains using the agar dilution method. Antiproliferative activity was determined by MTT test against Lung Carcinoma Cell Line (A549).

Result and Discussion: As a result of the studies, the TAS value of the plant was measured as 8.770 \pm 0.171 , TOS value as $14.590 \pm 0.191$ and OSI value as $0.167 \pm 0.005$. Inhibition of the plant extract was observed against standard bacteria and fungus strains at ranging from 50-200 $\mu \mathrm{g} / \mathrm{mL}$ concentrations. In addition, it was determined that the plant extract displayed strong antiproliferative activity due to the increase in concentration. As a result of these studies, it has been determined that G. glabra can be used as an important natural antioxidant, antimicrobial and anticancer agent.

Keywords: Antimicrobial, antioxidant, antiproliferative, Glycyrrhiza glabra, medicinal plants ÖZ
\end{abstract}

\footnotetext{
* Corresponding Author/Sorumlu Yazar: Nuh Korkmaz

e-mail / e-posta: korkmazhun@ @mail.com, Phone /Tel.: +905050227978
} 
Amaç: Alternatif tıp, insanllk tarihinde birçok hastalıkla mücadelede önemli bir yere sahiptir. Bu çalışmada Glycyrrhiza glabra L.'nin biyolojik aktivitesi araştırıldı.

Gereç ve Yöntem: Bitkinin kök kısımları etanol ile ekstrakte edildi. Antioksidan ve oksidan potansiyelleri Rel Assay kitleri kullanılarak belirlendi. Antimikrobiyal aktivite, agar seyreltme yöntemi kullanilarak standart bakteri ve mantar suşlarına karşı test edildi. Antiproliferatif aktivite, Lung Carcinoma Cell Line'a (A549) karşı MTT testi ile belirlendi.

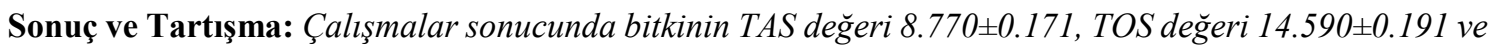
OSI değeri $0.167 \pm 0.005$ olarak ölçülmüştür. Bitki ekstraktının 50-200 $\mu \mathrm{g} / \mathrm{mL}$ konsantrasyon aralığında standart bakteri ve mantar suşlarına karşı inhibisyonu gözlemlendi. Ayrıca bitki ekstraktının konsantrasyon artışına bağlı olarak güçlü antiproliferatif aktivite gösterdiği belirlendi. Bu çalışmalar sonucunda G. glabra'nın önemli bir doğal antioksidan, antimikrobiyal ve antikanser ajanı olarak kullanılabileceği belirlenmistir.

Anahtar Kelimeler: Antimikrobiyal, antioksidan, antiproliferatif, Glycyrrhiza glabra, tıbbi bitkiler

\section{INTRODUCTION}

Many natural materials such as mushrooms, plants and animals are used in alternative medicine [1]. It occupies a very important place in the treatment of diseases due to the active substances produced by the plants. Many studies have shown that plants have anticancer, antioxidant, antimicrobial, antiproliferative, anti-inflammatory, DNA protective, antiallergic and hepatoprotective activities [2-4]. In our study, Glycyrrhiza glabra L. (Licorice) was used as a material.

Licorice; It is a plant belonging to the genus Glycyrrhiza glabra, of the genus Glycyrrhiza of the Papillionacease family. It is used for therapeutic purposes known in the history of ancient medicine in many civilizations such as Sumer, Mesopotamia, China, Greek and Egypt in the world. Among the aromatic and medicinal plants, the licorice plant is popularly known by 14 different names such as "biyam, dye, piyam, sweet root, etc." [5]. Licorice plant in the world at 12, while in Turkey in 6 species of yellow-blue or brown color, is a perennial shrub plant ranging between 30-160 cm in length [6]. The roots of the licorice plant are biologically known as a source of magnesium and silicon. In addition, the active ingredient in the composition of the licorice plant, glycyrrhizin is 50 times sweeter than tea sugar and 150 times sweeter than sucrose. Glycyrrhiza acid, which is found in the sweetness of the roots, and its calcium and potassium salts, two of the substances such as sucrose and mannite come from $[7,8]$. Therefore, as much more intense taste is obtained with less amount, it has been involved in the cuisine and food industry of many countries for centuries [9].

In addition, in the production of licorice honey, licorice sherbet, in the manufacture of tobacco, snuff and filter cigarettes, in the confectionery and beverage industry as a fragrance and flavoring, in cosmetics, velvet dyeing and shoe dyeing in the textile industry, making foam in fire fighting, in preparations prepared to kill insults, and in the food industry, there are areas of use such as adding fragrance to foods [10-12]. Licorice plant is widely used in food, confectionery, medicine and tobacco products as a flavoring agent known worldwide as "generally safe" (GRAS) [13]. In this study, antioxidant, oxidant, antimicrobial and antiproliferative activity of ethanol extract of root parts of $G$. glabra was determined. 


\section{MATERIAL AND METHOD}

\section{Laboratory Studies}

Plant samples were collected from Duhok (Iraq). Soil and dust particles were removed from the root parts of the plant. It was then dried under suitable conditions. After drying the plant parts were pulverized and weighed $30 \mathrm{~g}$. It was then extracted with ethanol for about 6 hours, for example at 50 ${ }^{\circ} \mathrm{C}$. The solvents of the extracts were removed in a rotary evaporator and crude extracts were obtained.

\section{Antioxidant Parameters}

The antioxidant and oxidant status of the plant extract was determined using Rel Assay TAS and TOS kits. TAS tests were performed according to the protocol specified in Erel [14] and Trolox was used as a calibrator. Results are shown in mmol Trolox equiv./L. TOS tests were performed according to the protocol specified in Erel [15] and hydrogen peroxide was used as a calibrator. Results are shown as $\mu \mathrm{mol} \mathrm{H}_{2} \mathrm{O}_{2}$ equiv./L. The oxidative stress index (OSI) was determined by proportioning the TOS value to the TAS value [16].

\section{Antimicrobial Activity Tests}

The antimicrobial activity of the root parts of the plant against EtOH extract bacteria and fungus strains was determined using the agar dilution method [17-19]. The plant extract was adjusted with distilled water at 800-12.5 $\mu \mathrm{g} / \mathrm{mL}$ concentrations. Bacterial strains were set in Muller Hinton Broth medium. Staphylococcus aureus ATCC 29213, S. aureus MRSA ATCC 43300, Enterococcus faecalis ATCC 29212, Escherichia coli ATCC 25922, Pseudomonas aeruginosa ATCC 27853 and Acinetobacter baumannii ATCC 19606 were used as bacterial strains. Fungus strains were pre-cultured in RPMI 1640 Broth medium. Candida albicans ATCC 10231, C. krusei ATCC 34135 and C. glabrata ATCC 90030 were used as fungus strains. The extract concentration that inhibits the growth of bacteria and fungus strains was determined as the MIC value. Results were expressed in $\mu \mathrm{g} / \mathrm{mL}$ [20-22].

\section{Antiproliferative Activity Tests}

The antiproliferative activity of the EtOH extract of the plant was determined by MTT test on A549 lung cancer cells. Cells were separated after 70-80\% confluence using $3.0 \mathrm{~mL}$ of Trypsin-EDTA solution (Sigma-Aldrich, MO, USA). It was then planted on plates and incubated for 24 hours. The plant extract $(25,50,100,200 \mu \mathrm{g} / \mathrm{mL})$ was then adjusted at different concentrations. After the incubation period, the supernatants were dissolved in growth medium and replaced with $1 \mathrm{mg} / \mathrm{mL}$ MTT (Sigma). It was then incubated at $37{ }^{\circ} \mathrm{C}$ until a purple precipitate formed. The supernatants were then removed and dissolved by adding dimethyl sulfoxide (DMSO) (Sigma-Aldrich, MO, USA) to MTT absorbed by cells. Subsequently, plates were read at $570 \mathrm{~nm}$ using an Epoch spectrophotometer (BioTek Instruments, Winooska, VT) [23]. 


\section{RESULT AND DISCUSSION}

\section{Antioxidant Activity}

In recent years, it is known that the basis of many diseases are due to oxidative stress caused by reactive oxygen species. Oxidative stress is due to the disproportion between the formation and neutralization of prooxidants [24]. The level of endogenous oxidant compounds resulting from environmental factors as a result of metabolic activities is highly toxic when they accumulate in organisms. The antioxidant defense system plays a role in reducing the effects of oxidant compounds. If the antioxidant defense system is insufficient, oxidative stress occurs. In such cases, supplemental antioxidants are important in reducing the effect of oxidative stress. In this context, it is very important to identify new natural antioxidant agents [25]. In our study, the antioxidant and oxidant potentials of G. glabra were determined. The results obtained are shown in Table 1 .

Table 1. Antioxidant and oxidant status of G. glabra.

\begin{tabular}{|l|l|l|l|l|}
\hline & & TAS $(\mathbf{m m o l} / \mathbf{L})$ & TOS $(\mu \mathrm{mol} / \mathbf{L})$ & OSI \\
\hline G. glabra & & $8.770 \pm 0.171$ & $14.590 \pm 0.191$ & $0.167 \pm 0.005$ \\
\hline
\end{tabular}

* Values are presented as mean \pm S.D.

In previous studies of G. glabra, it was reported that aqueous, methanol, ethanol extracts have antioxidant potential using different methods (Inhibition of b-carotene-linoleate bleaching, Hypochlorous acid-scavenging activity, Inhibition of myeloperoxidase-chlorinating system, Nitric oxide radical scavenging activity, Superoxide anion scavenging activity, Hydroxyl radical scavenging activity, DPPH radical scavenging activity, ABTS•+ cation Radical Scavenging, Fe+2/ascorbate induced lipid peroxidation assay, Reducing power) [26-29]. In our study, TAS, TOS and OSI values were determined for the first time by using Rel Assay kits of G. glabra. As a result of the studies, it has been determined that G. glabra has an important antioxidant activity. In addition, TAS values of $R$. coriaria var. zebaria, M. longifolia subsp. longifolia, A. calocephalum, S. papposa, F. platycarpa, T. spicata, G. tournefortii, R. crispus and A. millefolium reported in the literature were reported as 7.342, $3.628,5.853,5.314,5.688,8.399,6.831,6.758$ and $2.436 \mathrm{mmol} / \mathrm{L}$, respectively. TOS values were reported as 5.170, 4.046, 16.288, 24.199, 15.552, 6.530, 3.712, 5.802 and $2.839 \mu \mathrm{mol} / \mathrm{L}$, respectively. OSI values were reported as $0.071,0.112,0.278,0.456,0.273,0.078,0.054,0.086$ and 0.083 , respectively [30-38].

Compared to these studies, the TAS value of G. glabra was determined to be higher than $R$. coriaria var. zebaria, M. longifolia subsp. longifolia, A. calocephalum, S. papposa, F. platycarpa, T. spicata, G. tournefortii, $R$. crispus and A. millefolium. TAS value shows all of the antioxidant compounds produced in the plant [30]. As seen in our study, it has been determined that G. glabra has a very important antioxidant potential. 
When TOS values were examined, it was determined that G. glabra was lower than S. papposa and $F$. platycarpa, and higher than Rhus coriaria var. zebaria, Mentha longifolia subsp. longifolia, A. calocephalum, T. spicata, G. tournefortii, R. crispus and A. millefolium. The TOS value indicates all of the oxidant compounds produced by the environmental effects in the plant [30]. It is seen that the oxidant levels of the plant used in our study are at normal levels.

When OSI values were examined, it was determined that G. glabra was lower than A. calocephalum, S. papposa and $F$. platycarpa, and higher than $R$. coriaria var. zebaria, M. longifolia subsp. longifolia, T. spicata, G. tournefortii, R. crispus and A. millefolium. The OSI value shows how much oxidant compounds produced in the plants are suppressed by the antioxidant defense system. A low OSI value indicates that the antioxidant defense system of the plant works well [30]. In our study, it was determined that the antioxidant defense system of G. glabra was sufficient in suppressing oxidant compounds. As a result, it was determined that G. glabra has significant antioxidant activity.

\section{Antimicrobial Activity}

Today, many diseases occur due to microorganisms. Antibiotics are used extensively in the treatment of microorganism-based diseases. Today, resistant strains are emerging due to the unconscious use of antibiotics [39]. Antibiotics used against resistant microorganisms are insufficient. In addition, due to the possible side effects of chemical antibiotics, the tendency towards natural products is increasing. In this context, the discovery of new antimicrobial drugs is inevitable [40]. In this study, the activities of G. glabra against bacteria and fungi were investigated. The results obtained are shown in Table 2.

Table 2. Antimicrobial Activity of G. glabra.

\begin{tabular}{|c|c|c|c|c|c|c|c|c|c|}
\hline & $\mathbf{A}$ & B & $\mathbf{C}$ & D & $\mathbf{E}$ & $\mathbf{F}$ & $\mathbf{G}$ & $\mathbf{H}$ & $\mathbf{J}$ \\
\hline EtOH & 50 & 50 & 100 & 200 & 100 & 25 & 25 & 25 & 50 \\
\hline
\end{tabular}

* (A) S. aureus, (B) S. aureus MRSA, (C) E. faecalis, (D) E. coli, (E) P. aeruginosa, (F) A. baumannii, (G) C. glabrata, (H) C. albicans, (J) C. krusei

*200, 100, 50 and $25 \mu \mathrm{g} / \mathrm{mL}$ extract concentrations

In previous studies, it has been reported that methanol extracts of G. glabra are effective against Staphylococcus aureus, Bacillus megaterium, B. subtilis, Sarcina lutea, Salmonella paratyphi, S. typhi, Escherichia coli, Shigella dysenteriae, Vibrio minicus, V. parahemolyticus and Psedomonas aeruginosa at different concentrations [41]. In a different study, ethanol extracts of G. glabra were reported to be effective against Candida albicans, Staphylococcus aureus, Bacillus subtilis, Enterococcus faecalis, Escherichia coli, Pseudomonas aerouginosa and Klebsiella pneumoniae [42]. Ethanolic, hexane fraction, ethyl acetate fraction and methanol fraction of G. glabra have been reported to be effective against Staphylococcus aureus, Staphylococcus epidermidis, Streptococcus mutans, Bacillus subtilis, Enterococcus faecalis, Klebsiella pneumoniae, Salmonella typhi, Yersinia enterocolitica, Enterobacter 
aerogens and Escherichia coli [43]. In our study, G. glabra was determined to be effective against $A$. baumannii, C. glabrata and C. albicans at $25 \mu \mathrm{g} / \mathrm{mL}$, S. aureus, S. aureus MRSA and C. krusei at 50 $\mu \mathrm{g} / \mathrm{mL}$, E. faecalis and P. aeruginosa at $100 \mu \mathrm{g} / \mathrm{mL}$, E. coli at $200 \mu \mathrm{g} / \mathrm{mL}$ extract concentrations. As a result, it was determined that G. glabra has antibacterial and antifungal activities.

\section{Antiproliferative Activity}

Cancer is one of the leading causes of death in the world where uncontrolled growth is seen in one or more cells and surgery, chemotherapy and/or radiotherapy are applied in treatment steps [44]. Today, as a result of the increase in cancer incidence due to different reasons, treatments using cytotoxic drugs have become widespread [45]. Demand for cytotoxic drugs is expected to increase, especially in the coming years, due to the increase in the population sensitive to cancer. In this context, the detection of new natural anticancer agents is of great importance. Plants are important natural agents thanks to the metabolites they contain [46, 47]. In our study, the activity of EtOH extract of G. glabra on Lung Carcinoma Cell Line (A549) was determined. The findings obtained are shown in figure 1.

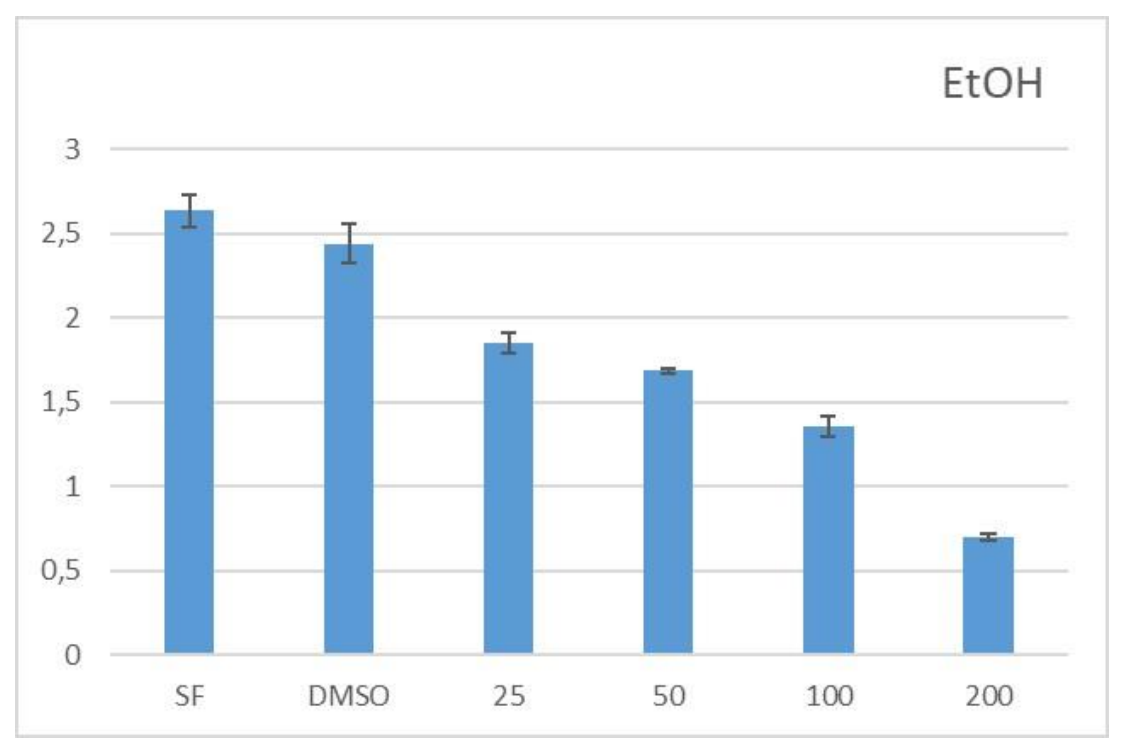

Figure 1. Antiproliferative activity of G. glabra

In previous studies, chloroform, methanol and water extracts of G. glabra were reported to be effective against MCF7 cell line [48]. Essential oil of G. glabra has been reported to be effective at different levels on MCF-7 and HT29 cell lines [49]. In our study, it was determined that EtOH extract of G. glabra exhibited strong cytotoxic effects on the A549 cell line due to the dose increase. The strongest activity was seen at $200 \mu \mathrm{g} / \mathrm{mL}$ concentration. As a result, it has been determined that $G$. glabra can be used as a natural anticancer source. 


\section{Conclusion}

In this study, some medicinal properties of the root parts of G. glabra were determined. As a result of the studies, it was determined that the root extracts of the plant exhibit significant antioxidant, antimicrobial and antiproliferative activity. As a result, it is thought that G. glabra can be used as a natural material in pharmacological designs.

\section{AUTHOR CONTRIBUTIONS}

Concept: F.S.M., N.K., M.G., A.E.S., M.S.; Design: F.S.M., N.K., M.G., A.E.Ş., M.S; Control: F.S.M., N.K., M.G., A.E.Ş., M.S.; Sources: F.S.M.,; Materials: F.S.M., N.K., M.G., A.E.Ş., M.S.; Data Collection and/or processing: F.S.M., N.K., M.G., A.E.S., M.S.; Analysis and/or interpretation: F.S.M., N.K., M.G., A.E.Ş., M.S.; Literature review: F.S.M., N.K., M.G., A.E.Ş., M.S.; Manuscript writing: F.S.M., N.K.; Critical review: F.S.M., N.K., M.G., A.E.S., M.S.; Other: F.S.M, N.K., M.S.

\section{CONFLICT OF INTEREST}

The authors declare no conflict of interest.

\section{REFERENCES}

1. Korkmaz, A.I., Akgul, H., Sevindik, M., Selamoglu, Z. (2018). Study on determination of bioactive potentials of certain lichens. Acta Alimentaria, 47(1), 80-87. [CrossRef]

2. Ben-Shabat, S., Yarmolinsky, L., Porat, D., Dahan, A. (2020). Antiviral effect of phytochemicals from medicinal plants: applications and drug delivery strategies. Drug Delivery and Translational Research, 10(2), 354-367. [CrossRef]

3. Li, Y., Kong, D., Fu, Y., Sussman, M.R., Wu, H. (2020). The effect of developmental and environmental factors on secondary metabolites in medicinal plants. Plant Physiology and Biochemistry, 148, 80-89. [CrossRef]

4. Mohammed, F.S., Pehlivan, M., Sevindik, E., Akgul, H., Sevindik, M., Bozgeyik, I., Yumrutas, O. (2021). Pharmacological properties of edible Asparagus acutifolius and Asparagus officinalis collected from North Iraq and Turkey (Hatay). Acta Alimentaria, 50(1), 136-143. [CrossRef]

5. Pastorino, G., Cornara, L., Soares, S., Rodrigues, F., Oliveira, M.B.P. (2018). Liquorice (Glycyrrhiza glabra): A phytochemical and pharmacological review. Phytotherapy research, 32(12), 2323-2339. [CrossRef]

6. Kılınç, F., Demircan, F., Yıldırım, Y., Yılmaz, Z., Pekkolay, Z., Tuzcu, A.K. (2014). Meyan Kökü (Likoris) Kullanımına Bağlı Hipertansiyon ve Hipokalemi ile Seyreden 5 Vakanını Değerlendirilmesi. Sakarya Tip Dergisi, 4, 186-190. [CrossRef] 
7. Nazari, S., Rameshrad, M., Hosseinzadeh, H. (2017). Toxicological effects of Glycyrrhiza glabra (licorice): a review. Phytotherapy research, 31(11), 1635-1650. [CrossRef]

8. Alagawany, M., Elnesr, S.S., Farag, M.R., El-Hack, A., Mohamed, E., Khafaga, A.F., Taha, A.E., Tiwari, R., Yatoo, M.I., Bhatt, P., Marappan, G., Dhama, K. (2019). Use of licorice (Glycyrrhiza glabra) herb as a feed additive in poultry: Current knowledge and prospects. Animals, 9(8), 536. [CrossRef]

9. Cuvelier, M. E., Berset, C., Richard, H. (1994). Antioxidant Constituents in Sage (Salvia officinalis). Journal of Agricultural and food chemistry, 42, 665-669. [CrossRef]

10. Kikuzaki, H., Nakatani, N. (1993). Antioxidant Effects of Some ginger constituents. Journal of food science, 58, 1407-1410. [CrossRef]

11. Shahidi, F. (2000). Antioxidants in Food and Food Antioxidants. Food/nahrung, 44, 158-163. [CrossRef]

12. Dang, M.N., Takácsová, M., Nguyen, D.V., Kristiánová, K. (2001). Antioxidant Activity of Essential Oils from Various Spices. Food/nahrung, 45, 64-66. [CrossRef]

13. Jiang, J., Zhang, X., True, A.D., Zhou, L., Xiong, Y.L. (2013). Inhibition of Lipid Oxidation and Rancidity in Precooked Pork Patties by Radical-Scavenging Licorice (Glycyrrhiza glabra) Extract. Journal of food science, 78: 1686-1694. [CrossRef]

14. Erel, O. (2004). A novel automated direct measurement method for total antioxidant capacity using a new generation, more stable ABTS radical cation. Clinical biochemistry, 37(4), 277285. [CrossRef]

15. Erel, O. (2005). A new automated colorimetric method for measuring total oxidant status. Clinical biochemistry, 38(12), 1103-1111. [CrossRef]

16. Sevindik, M., Akgul, H., Akata, I., Alli, H., Selamoglu, Z. (2017). Fomitopsis pinicola in healthful dietary approach and their therapeutic potentials. Acta Alimentaria, 46(4), 464-469. [CrossRef]

17. CLSI (The Clinical and Laboratory Standards Institute). (2012). Antimicrobial Susceptibility Testing of Anaerobic Bacteria; Approved Standard—Eighth Edition (M11-A8). [CrossRef]

18. EUCAST (European Committee on Antimicrobial Susceptibility Testing). (2014). Breakpoint tables Fungal isolate for interpretation of MICs. Version 7.0.

19. EUCAST (European Committee on Antimicrobial Susceptibility Testing). (2015). Breakpoint tables for Bacteria interpretation of MICs and zone diameters, Version 5.0.

20. Bauer, A.W., Kirby, W.M., Sherris, J.C., Turck, M. (1966). Antibiotic susceptibility testing by a standardized single disk method. American Journal of Clinical Pathology, 45, 493-96.

21. Hindler, J., Hochstein, L., Howell, A. (1992). Preparation of routine media and reagents used in antimicrobial susceptibility testing. Part 1. McFarland standards, p. 5.19.1-5.19.6. In H. D. Isenberg (ed) Clinical microbiology procedures handbook, vol. 1. American Society for Microbiology, Washington, D.C. 
22. Matuschek, E., Brown, D.F., Kahlmeter, G. (2014). Development of the EUCAST disk diffusion antimicrobial susceptibility testing method and its implementation in routine microbiology laboratories. Clinical Microbiology and Infection 20: 255-266. [CrossRef]

23. Bal, C., Akgul, H., Sevindik, M., Akata, I., Yumrutas, O. (2017). Determination of the antioxidative activities of six mushrooms. Fresenius Environmental Bulletin, 26(10), 6246-6252.

24. Frattaruolo, L., Carullo, G., Brindisi, M., Mazzotta, S., Bellissimo, L., Rago, V., Curcio, R., Dolce, V., Aiello, F., Cappello, A. R. (2019). Antioxidant and anti-inflammatory activities of flavanones from Glycyrrhiza glabra L.(licorice) leaf phytocomplexes: Identification of licoflavanone as a modulator of NF-kB/MAPK pathway. Antioxidants, 8(6), 186. [CrossRef]

25. Sakihama, Y., Cohen, M. F., Grace, S. C., Yamasaki, H. (2002). Plant phenolic antioxidant and prooxidant activities: phenolics-induced oxidative damage mediated by metals in plants. Toxicology, 177(1), 67-80. [CrossRef]

26. Visavadiya, N. P., Soni, B., Dalwadi, N. (2009). Evaluation of antioxidant and anti-atherogenic properties of Glycyrrhiza glabra root using in vitro models. International journal of food sciences and nutrition, 60(sup2), 135-149. [CrossRef]

27. Cheel, J., Van Antwerpen, P., Tůmová, L., Onofre, G., Vokurková, D., Zouaoui-Boudjeltia, K., Vanhaeverbeek, M., Nève, J. (2010). Free radical-scavenging, antioxidant and immunostimulating effects of a licorice infusion (Glycyrrhiza glabra L.). Food Chemistry, 122(3), 508-517. [CrossRef]

28. Mehreen, L., Lubna, I., Nudrat, F., Kauser, S., Nighat, A., Mansoor, A. (2012). Evaluation of antioxidant and urease inhibition activities of roots of Glycyrrhiza glabra. Pakistan Journal of Pharmaceutical Sciences, 25(1): 99-102

29. Durmaz, H., Hülül, M., Celik, H. (2018). Meyan (Glycyrrhiza glabra L.) Bitkisinin Antibakteriyel ve Antioksidan Aktiviteleri. Harran Üniversitesi Veteriner Fakültesi Dergisi, 7 , 37-41. [CrossRef]

30. Mohammed, F. S., Akgul, H., Sevindik, M., Khaled, B. M. T. (2018). Phenolic content and biological activities of Rhus coriaria var. zebaria. Fresenius Environmental Bulletin, 27(8), 5694-5702.

31. Sevindik M, Akgul, H, Pehlivan M, Selamoglu Z (2017) Determination of therapeutic potential of Mentha longifolia ssp. longifolia. Fresenius Environmental Bulletin 26(7), 4757-4763

32. Mohammed, F. S., Karakaş, M., Akgül, H., Sevindik, M. (2019). Medicinal properties of Allium calocephalum collected from Gara Mountain (Iraq). Fresenius Environmental Bulletin, 28(10), 7419-7426.

33. Mohammed, F. S., Günal, S., Şabik, A. E., Akgül, H., Sevindik, M. (2020). Antioxidant and Antimicrobial activity of Scorzonera papposa collected from Iraq and Turkey. Kahramanmaraş Sütçü İmam Üniversitesi Tarım ve Doğa Dergisi, 23(5), 1114-1118. [CrossRef]

34. Mohammed, F. S., Günal, S., Pehlivan, M., Doğan, M., Sevindik, M., Akgül, H. (2020). Phenolic content, antioxidant and antimicrobial potential of endemic Ferulago platycarpa. Gazi University Journal of Science, 33(4), 670-677. [CrossRef] 
35. Mohammed, F. S., Şabik, A. E., Sevindik, E., Pehlivan, M., Sevindik, M. (2020). Determination of Antioxidant and Oxidant Potentials of Thymbra spicata Collected from Duhok-Iraq. Turkish Journal of Agriculture-Food Science and Technology, 8(5), 1171-1173. [CrossRef]

36. Saraç, H., Demirbaş, A., Daştan, S. D., Ataş, M., Çevik, Ö., Eruygur, N. (2019). Evaluation of Nutrients and Biological Activities of Kenger (Gundellia tournefortii L.) Seeds Cultivated in Sivas Province. Turkish Journal of Agriculture-Food Science and Technology, 7(sp2), 52-58. [CrossRef]

37. Daştan, S. D., Durukan, H., Demirbaş, A., Dönmez, E. (2019). Bioactivity and Therapeutic Properties of Evelik (Rumex crispus), A Naturally Growing and Edible Plant in Sivas Province. Turkish Journal of Agriculture-Food Science and Technology, 7(sp2), 67-71. [CrossRef]

38. Saraç, H., Durukan, H., Demirbaş, A. (2021). Nutrient Concentrations and Antioxidant Activity of Achillea millefolium L.(Yarrow), One of the Important Medicinal Plants. Turkish Journal of Agriculture-Food Science and Technology, 9(3), 590-594. [CrossRef]

39. Rios, J. L., Recio, M. C. (2005). Medicinal plants and antimicrobial activity. Journal of ethnopharmacology, 100(1-2), 80-84. [CrossRef]

40. Jafarzadeh, S., Jafari, S. M., Salehabadi, A., Nafchi, A. M., Kumar, U. S. U., Khalil, H. A. (2020). Biodegradable green packaging with antimicrobial functions based on the bioactive compounds from tropical plants and their by-products. Trends in Food Science \& Technology, 100, 262-277. [CrossRef]

41. Sultana, S., Haque, A., Hamid, K., Urmi, K. F., Roy, S. (2010). Antimicrobial, cytotoxic and antioxidant activity of methanolic extract of Glycyrrhiza glabra. Agric Biol JN Am, 1(5), 95760. [CrossRef]

42. Irani, M., Sarmadi, M., Bernard, F. (2010). Leaves antimicrobial activity of Glycyrrhiza glabra L. Iranian journal of pharmaceutical research: IJPR, 9(4), 425.

43. Gupta, V. K., Fatima, A., Faridi, U., Negi, A. S., Shanker, K., Kumar, J. K., Rahuja, N., Luqman, S., Sisodia, B. S., Saikia, D., Darokar, M. P., Khanuja, S. P. (2008). Antimicrobial potential of Glycyrrhiza glabra roots. Journal of ethnopharmacology, 116(2), 377-380. [CrossRef]

44. Nussbaumer, S., Bonnabry, P., Veuthey, J. L., Fleury-Souverain, S. (2011). Analysis of anticancer drugs: a review. Talanta, 85(5), 2265-2289. [CrossRef]

45. Tariq, A., Sadia, S., Pan, K., Ullah, I., Mussarat, S., Sun, F., Abiodun, O. O., Batbaatar, A., Li, Z., Song, D., Xiong, D., Ullah, R., Khan, R., Basnet, B. H., Kumar, B., Islam, R., Adnan, M. (2017). A systematic review on ethnomedicines of anti-cancer plants. Phytotherapy Research, 31(2), 202-264. [CrossRef]

46. Buyel, J. F. (2018). Plants as sources of natural and recombinant anti-cancer agents. Biotechnology advances, 36(2), 506-520. [CrossRef]

47. Aumeeruddy, M. Z., Mahomoodally, M. F. (2021). Global documentation of traditionally used medicinal plants in cancer management: A systematic review. South African Journal of Botany, 138, 424-494. [CrossRef] 
48. Rathi, S. G., Suthar, M., Patel, P., Bhaskar, V. H., Rajgor, N. B. (2009). In-vitro cytotoxic screening of Glycyrrhiza glabra L.(Fabaceae): A natural anticancer drug. Journal of Young Pharmacists, 1(3), 239. [CrossRef]

49. Nazmi, S. A., Nourazarian, A., Bahhaj, R., Khakikhatibi, F. (2018). The anticancer effect of Arctium lappa and Glycyrrhiza glabra on HT-29 colon cancer and MCF-7 breast cancer cell lines. cancer, 6, 7. 